\title{
Effect of Coal Dust Exposure on the SOD Activity and the Oxidative DNA Damage in Asthmatic Mice
}

\author{
Windy Yuliana Budianto ${ }^{1,2, *}$, Husnul Khotimah ${ }^{3}$, Eko Suhartono ${ }^{4}$ \\ ${ }^{1}$ Master Program of Biomedical Sciences, Faculty of Medicine, Universitas Brawijaya, Jl. Veteran, Malang 65145, Indonesia \\ ${ }^{2}$ Department of Pediatric Nursing, Faculty of Medicine, Universitas Lambung Mangkurat, Jl. Ahmad Yani Km.36, Banjarbaru 70712, Indonesia \\ ${ }^{3}$ Department of Farmacology, Faculty of Medicine, Universitas Brawijaya, Jl. Veteran, Malang 65145, Indonesia \\ ${ }^{4}$ Departement of Medical Chemistry/Biochemistry, Faculty of Medicine, Universitas Lambung Mangkurat, Jl. Ahmad Yani Km.36, \\ Banjarbaru 70712, Indonesia \\ *Corresponding author. E-mail:windyulianabudianto@gmail.com
}

Received date: Oct 7, 2018; Revised date: Jan 2, 2019; Accepted date: Jan 11, 2019

\section{Abstract}

$\mathrm{B}$ ACKGROUND: Coal dust is known to trigger hypersensitivity and inflammation of the respiratory tract as it increases oxidative stress leading to asthma. To date, the relationship of coal dust exposure in the pathomechanism of asthma remains unclear. This study was aimed to examine the effect of coal dust exposure on the superoxide dismutase (SOD) activity and the oxidative DNA damage indicated by increased serum 8-hydroxy-2' -deoxyguanosine $(8-\mathrm{OHdG})$ in asthmatic mice.

METHODS: Twenty-four female balb/c mice were divided into four groups. The first group was the control group. The second group was the negative control group which composed of mice exposed to coal dust particles. The third group was composed of ovalbumin (OVA)-sensitized mice. The fourth group was composed of OVA-sensitized mice and exposed to coal dust particles. The inflammatory process was identified by serum interleukin (IL)-13 concentration using Enzyme-linked Immunosorbent Assay (ELISA) method. Meanwhile, the oxidative stress was examined by measuring the SOD activity using the Nitro Blue Tetrazolium (NBT) method, and the 8-OHdG concentration was quantified by ELISA method.

RESULTS: There was an increasing IL-13 in OVAtreated coal dust exposed group along with the increment of $8-\mathrm{OHdG}$ (statistically not significant). SOD activity measured in serum was decreased in all groups $(p>0.05)$. Combination of OVA and coal dust showed the worst effect on IL-13, 8-OHdG and SOD activity.

CONCLUSION: Coal dust exposure for four weeks does not adequately induce the oxidative DNA damage in asthmatic mice.

KEYWORDS: asthma, coal dust, IL-13, SOD, 8-OHdG

Indones Biomed J. 2019; 11(2): 159-66

\section{Introduction}

Asthma is a chronic respiratory tract disorder indicated by recurrent inflammation of the respiratory tract. It is also commonly accompanied by shortness of breath accompanied with wheezing, heavy chest sensation, coughing, and airway remodeling caused by the increasing infiltration of inflammatory cells including mast cells, eosinophils and lymphocytes.(1,2) Many studies have been conducted on asthma, including experimental model. Astamthic symptoms in experimental models, can be induced by ovalbumin (OVA).(3-5) The induction of OVA leads to T-helper II (Th2) activation which secretes interleukin (IL)-4, IL-5 and IL-13 leading to activation of inflammatory cells, an increment of mucus production, airway bronchoconstriction and respiratory tract remodeling.(5-7) The sensitization of chicken OVA via 
intraperitoneal administration and inhalation of 1\% OVA diluted with $8 \mathrm{~mL} \mathrm{NaCl}$ in the mice model, showed that IL-4 receptor expression, inflammatory cell infiltration, and eosinophils were increased. These changes the airway wall structure.(8)

The epidemiological data reported that the incidence of asthma will rise from 235 million to 400 million worldwide between 2016-2025.(9) Based on the data of Basic Health Research/Riset Kesehatan Dasar (RISKESDAS) in 2013, the proportion of Indonesian citizens who suffered asthma have reached $4.5 \%$ of the total population. Approximately, $6.4 \%$ of them was in South Kalimantan.(10)

Asthma can be aggravated by continuous exposure to allergens. One of the allergens found in the South Kalimantan is coal dust, which is the result of the coal mining activity. $(1,11,12)$ The coal dust in the air was resulted from the coal mining. The inhaled cold dust through the respiratory tract can cause respiratory tract hypersensitivity, inflammation and oxidative stress. Coal dust penetrating the respiratory tract will attract alveolar macrophages and trigger the secretion of inflammatory mediators. This process will also increase the production of reactive oxygen species (ROS) which may cause oxidative damage. $(13,14)$ Oxidative damage of proteins indicated by the increasing carbonyl protein level and thiobarbituric acid-reactive species (TBARS) in the lung occurs due to the coal dust exposure.(15) Previous studies showed that the particulate matter (PM) 10 coal dust exposure induced lipid peroxidation as indicated by the increasing malondialdehyde (MDA) level in the lung and the bronchoalveolar lavage (BAL) fluid in mice.(16)

The damage was not only occurred in the lung tissue but also systematically. Several studies reported that there was an increment of serum MDA in mice exposed to coal dust for 24 hours in 14 days.(17) MDA is a marker of lipid peroxidative damage, whereas oxidative damage to DNA is characterized by the formation of 8-hydroxy-2' -deoxyguanosine (8-OHdG).(18) Another study identified an increment of 8-OHdG concentration in the serum and sputum of patients with chronic obstructive pulmonary disease (COPD).(19)

To date, the relationship of coal dust exposure in the pathomechanism of asthma remains unclear. Therefore, this study was conducted to examine the effect of coal dust exposure on the Superoxide dismutase SOD activity and the oxidative DNA damage indicated by the increased serum 8-OHdG in asthmatic mice.

\section{Methods}

This study has obtained the ethical approval from the health research ethics committee of the Faculty of Medicine, Universitas Lambung Mangkurat, Banjarmasin, Indonesia with the certificate number of No.895/ KEPK-FK UNLAM/ $\mathrm{EC} / \mathrm{VIII} / 2018$. In general, the research method was explained in Figure 1.

\section{Animal and Research Design}

The animal used in this study were female balb/c mice, aged 8-10 weeks, weighing of 20-30 g, gathered from Pusat Veterinaria Farma Surabaya, Indonesia. The acclimatization of balb/c mice was conducted for 7 days in the pharmacology laboratory of the Faculty of Medicine, Universitas Brawijaya. During the acclimatization process, mice were treated according to the laboratory standards, they were placed in a similar conditioned housing (temperature of $25 \pm 2^{\circ} \mathrm{C}, 12 / 12$ hours of light and dark cycles) and were given ad libitum access to food and drinks.

Twenty-four female balb/c mice were divided into 4 groups using a simple random method. The control group administered with $\mathrm{NaCl}$ via intraperitoneal injection and nebulized inhalation of $8 \mathrm{~mL} 0.9 \% \mathrm{NaCl}$. The coal dust group was composed of mice exposed to $12.5 \mathrm{mg} / \mathrm{m}^{3}$ PM5 coal dust for four weeks. The OVA group was composed of OVA-sensitized mice by peritoneal injection and inhalation of $1 \%$ OVA diluted in $8 \mathrm{~mL} \mathrm{NaCl}$, three times a week for 8 weeks. The combination OVA and coal dust group was composed of OVA-sensitized mice by peritoneal injection and inhalation of $1 \%$ OVA diluted in $8 \mathrm{~mL} \mathrm{NaCl}$, three times a week for 8 weeks, and exposed to inhalation of $12.5 \mathrm{mg} /$ $\mathrm{m}^{3}$ PM5 coal dust particles for 4 weeks.

\section{Preparation and Coal Dust Exposure}

The coal dust particles were produced using pulverizer consisting of Ball, Ring, and Raymond Mill at Carsurin Coal Laboratory in Banjarmasin. The process produced coal dust particles with a diameter of $75 \mu \mathrm{m}$. Coal dust particle that was engineered to reach the lower respiratory tract was confirmed to have the diameter of fewer than 5 $\mu \mathrm{m}$ (PM5). It was obtained by filtering the coal dust that has been grinded priorly using a zifon polyvinyl chloride (PVC) filter. The concentration of $12.5 \mathrm{mg} / \mathrm{m}^{3}$ PM5 coal dust exposure was prescribed based on the previous study. (16) The coal dust exposure in this study was performed for 
A

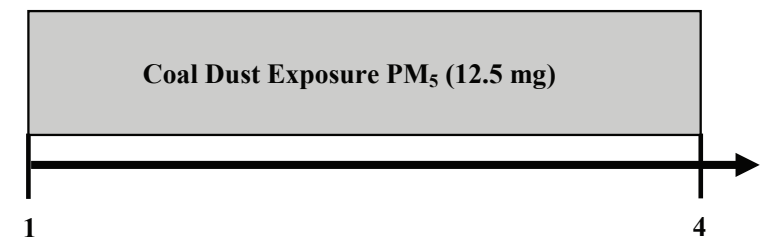

Week 1

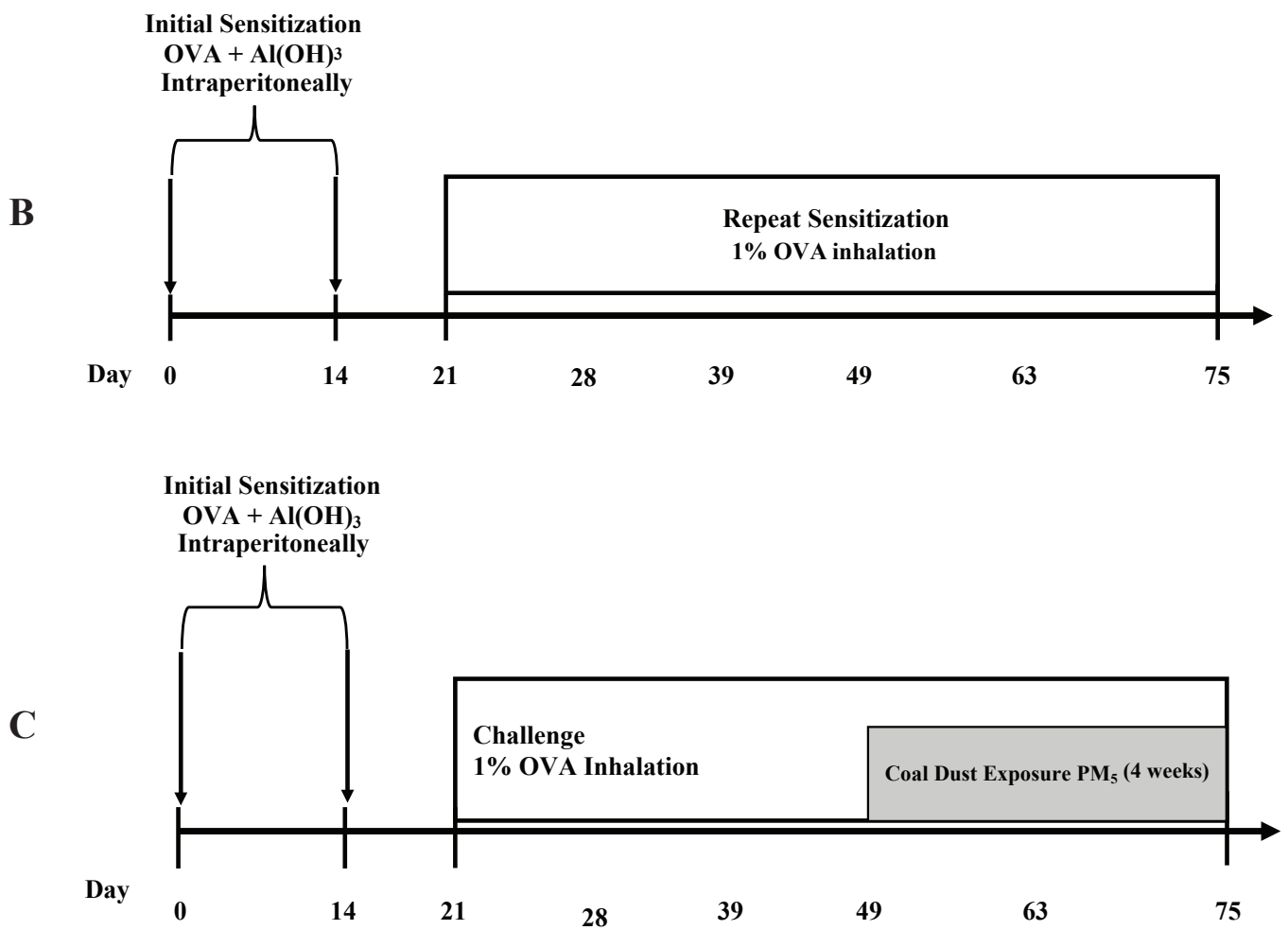

Figure 1. The experimental protocol. A: Balb/c mice were induced with coal dust exposure for 4 weeks. B: Balb/c mice were sensitized by injecting a mixture of OVA with aluminium hydroxide and then challenged with 1\% OVA concentration of aerosolized OVA for 8 weeks (three time a week). C: Balb/c mice were sensitized by injection of OVA and aerosolized OVA and then challenged with $12.5 \mathrm{mg} / \mathrm{m}^{3} \mathrm{coal}$ dust exposure PM5 for 4 weeks.

4 weeks (Figure 1A). Based on the previous research, coal dust exposure for 4 weeks can cause oxidative stress in the body. The coal dust exposure was conducted using special exposure chamber with a duration of 60 minutes daily for 4 weeks in Pharmacology Laboratory, Faculty of Medicine, Universitas Brawijaya.

\section{OVA Sensitization}

OVA sensitization was carried out according to the previous research.(8) The OVA used was albumin from crude Dried Egg White (Product No. A0198, TCI Chemical, Tokyo, Japan). The initial sensitization was performed by intraperitoneally injecting $10 \mu \mathrm{g}$ of OVA and $1 \mathrm{mg}$ of $\mathrm{Al}(\mathrm{OH})_{3}$ in $0.5 \mathrm{~mL}$ of $\mathrm{NaCl}$ on day 0 and 14 . The re-sensitization was performed on day 21 by inhalation of $1 \%$ OVA diluted in $8 \mathrm{~mL} \mathrm{NaCl}$ using Omron Ultrasonic Nebulizer
(Type NE-U17, Konotsubo, Kyoto, Japan) for 20 minutes periodically three times a week for 8 weeks (Figure 1B). The re-sensitization OVA was carried out up to the day 75 . Meanwhile, a combination of OVA and coal dust exposure was also carried out (Figure 1C). OVA sensitization method was added by 60 minutes exposure of $12.5 \mathrm{mg} / \mathrm{m}^{3}$ PM5 coal dust daily, which was carried out from day 49 until day 75 for 4 weeks.

\section{Serum Sample}

The serum was obtained after the mice were sacrificed by $0.1 \mathrm{~mL} / 20 \mathrm{gBB}$ ketamine/xylazine injection intraperitoneally. The heart blood was collected on a serum tube, and it was centrifuged for 10 minutes at $6,000 \mathrm{rpm}$ at $4^{\circ} \mathrm{C}$. The serum formed was collected in a $1.5 \mathrm{~mL}$ Eppendorf tube and was stored. 


\section{IL-13 Concentration Measurement}

The concentration of IL-13 in the sample serum was measured using the mouse IL-13 enzyme-linked immunosorbent assay (ELISA) kit (Cat. \#E0019Mo, Bioassay Technology Laboratory, Shanghai, China) with sensitivity $0.52 \mathrm{ng} / \mathrm{L}$. The analysis was done according to detail procedures in the kit.

\section{Superoxide Dismutase (SOD) Activity Measurement}

The examination of SOD activity was performed by employing the nitro blue tetrazolium (NBT) method according to Bannister and Calabrese.(20) Onehundred $\mu \mathrm{L}$ sample serum was then mixed with $200 \mu \mathrm{L}$ ethylenediaminetetraacetic acid (EDTA) $100 \mathrm{mM}, 100$ $\mu \mathrm{L}$ NBT 25 units, $100 \mu \mathrm{L}$ Xanthine $25 \mathrm{mM}$, and $100 \mu \mathrm{L}$ Xanthine oxidase 1 unit. The solution was then incubated for 30 minutes at $37^{\circ} \mathrm{C}$, and $500 \mu \mathrm{L}$ of buffer and distilled water were added until $3 \mathrm{~mL}$. The reaction results were then analyzed using UV-Vis spectrophotometer (UV-1700 Series, Shimadzu, Kyoto, Japan) at $580 \mathrm{~nm}$ wavelength.

\section{8-OHdG Concentration Measurement}

The concentration of $8-\mathrm{OHdG}$ in the sample serum was measured using mouse 8-Hydroxy-deoxyguanosine ELISA kit (Cat. \#E0187Mo, Bioassay Technology Laboratory) with sensitivity $0.053 \mathrm{ng} / \mathrm{mL}$. The $50 \mu \mathrm{L}$ of standard solution, $10 \mu \mathrm{L}$ anti-8-OHdG antibody, and $50 \mu \mathrm{L}$ of streptavidinhorseradish peroxidase (HRP) were added into the standard well. Then, $40 \mu \mathrm{L}, 10 \mu \mathrm{L}$ anti-8-OHdG antibody, and 50 $\mu \mathrm{L}$ of streptavidin-HRP were added into the sample well. The solution was covered with a sealer for 60 minutes at $37^{\circ} \mathrm{C}$. Then, the well was washed five times using $0.35 \mathrm{~mL}$ wash buffer and was dried. Fifty $\mu \mathrm{L}$ of substrate solution A and $50 \mu \mathrm{L}$ of substrate solution B were added in each well, and incubated for 10 minutes at $37^{\circ} \mathrm{C}$ in a dark room. The solution reacted as it appeared blue, $50 \mu \mathrm{L}$ of stop solution was added subsequently as it turned yellow. The optical density (OD) of the samples were obtained using a microplate reader at a wavelength of $450 \mathrm{~nm}$. Finally, its concentration was obtained by converting the OD value to concentration using the standard curve equation obtained from the measurement of the $8-\mathrm{OHdG}$ standard.

\section{Statistical Analysis}

The results of the data are presented in mean value $( \pm \mathrm{SD})$. Shapiro-Wilk and Levene's test was employed to analyze normality and the homogeneity of the data. A parametric one-way ANOVA test followed by post hoc test was performed to quantify the difference of the data (SOD activity, IL-13 concentration) between groups. Meanwhile, the differences in the concentration of $8-\mathrm{OHdG}$ serum in each group were analyzed by the Kruskal Walis nonparametric test. The statistical analyses were conducted using SPSS version 20.0 (SPSS Inc., Chicago, USA), with a significance level of $p<0.05$.

\section{Results}

\section{The Concentration of IL-13}

IL-13 serum concentration of all treatment groups was presented in Figure 2. The was homogenous (Lavene's test: $p=0.107 ; p>0.05$ ). The normality test using the ShapiroWilk test confirmed that the data was distributed normally $(p=0.526 ; p>0.05)$. Therefore, tha ANOVA test can be conducted. The ANOVA test analysis showed the $p=0.188$ ( $p>0.05$ ), indicating that there was no significant difference between groups.

\section{The SOD Activity}

The SOD serum activity data was tested for its homogeneity and normality employing the same statistical procedures performed in IL-13 concentration data. It was identified that the data were normally distributed and homogeneous ( $p=0.539$ and $p=0.174$ respectively; $p>0.05$ ). Therefore, the parametric ANOVA test was conducted and showed the $p=0.072(p>0.05)$. This results indicated that there was no significant difference between groups (Figure 3 ).

\section{The concentration of 8-OHdG}

Figure 4 presents the mean of the concentration of serum 8-OHdG for each group in this study. According to the Shapiro Wilk test, the data were considered normally distributed ( $p=0.477 ; p>0.05$ ). Levene test was conducted subsequently and showed that the data wasn't homogenous ( $p=0.016 ; p<0.05$ ) respectively. Thus, the concentration of serum $8-\mathrm{OHdG}$ was statistically analyzed using the nonparametric Kruskal Wallis test. There was no significant difference in 8 -OHdG concentration between groups $(p=0.571 ; p>0.05)$.

\section{Discussion}

OVA sensitization and PM5 coal dust exposure have a negative effect on the respiratory tract. OVA sensitization was identified to cause the inflammation and hyperactivity of the respiratory tract.(6,7) Meanwhile, the exposure of 


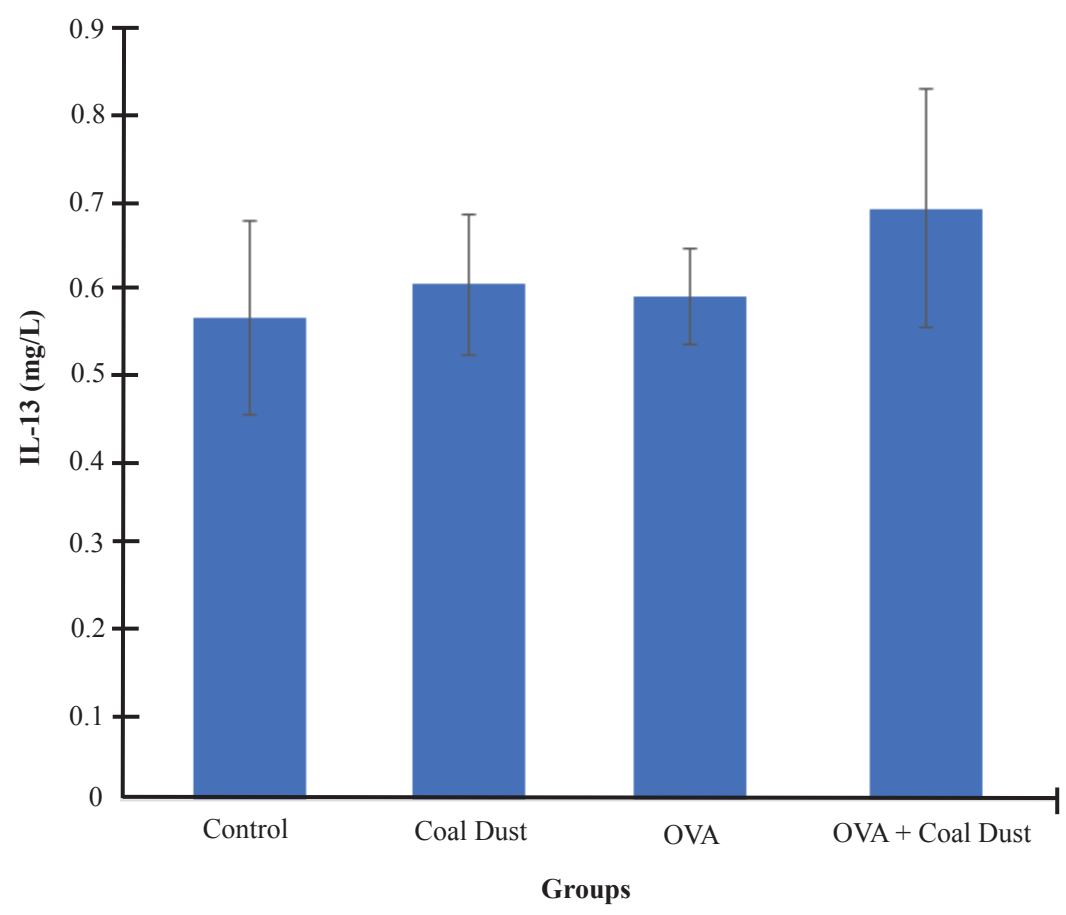

Figure 2. The concentration of serum IL-13. The graph presented that coal dust, OVA and the combination of OVA and coal dust tend to increase the IL-13 level. The highest level was shown at the combination of OVA and coal dust group.
PM5 coal dust can worsen the hyperreactivity conditions of the respiratory tract and the inflammatory state as it promotes the redox reactions. $(13,14)$ This study is aimed to determine the effect of coal dust exposure on the SOD activity and the oxidative DNA damage indicated by increased serum 8-OHdG in asthma mice model. OVA sensitization of this study was able to induce allergic asthma mice model. The results of this study are in line with the previous study which showed that ovalbumin induction in female balb/c mice causes similar human asthma symptoms.(6)
The results of this study indicated that coal dust exposure can increase the concentration of IL-13 serum compared to OVA sensitization group only. However, the increment was not statistically significant. The combination of OVA and coal dust exposure increased the concentration of IL-13 serum with no statistical significance. It is assumed that the administration of OVA for 8 weeks was not adequate to cause allergic inflammatory reactions systemically. The allergen sensitization (OVA) in the experimental models can stimulate the allergic inflammation. The allergic

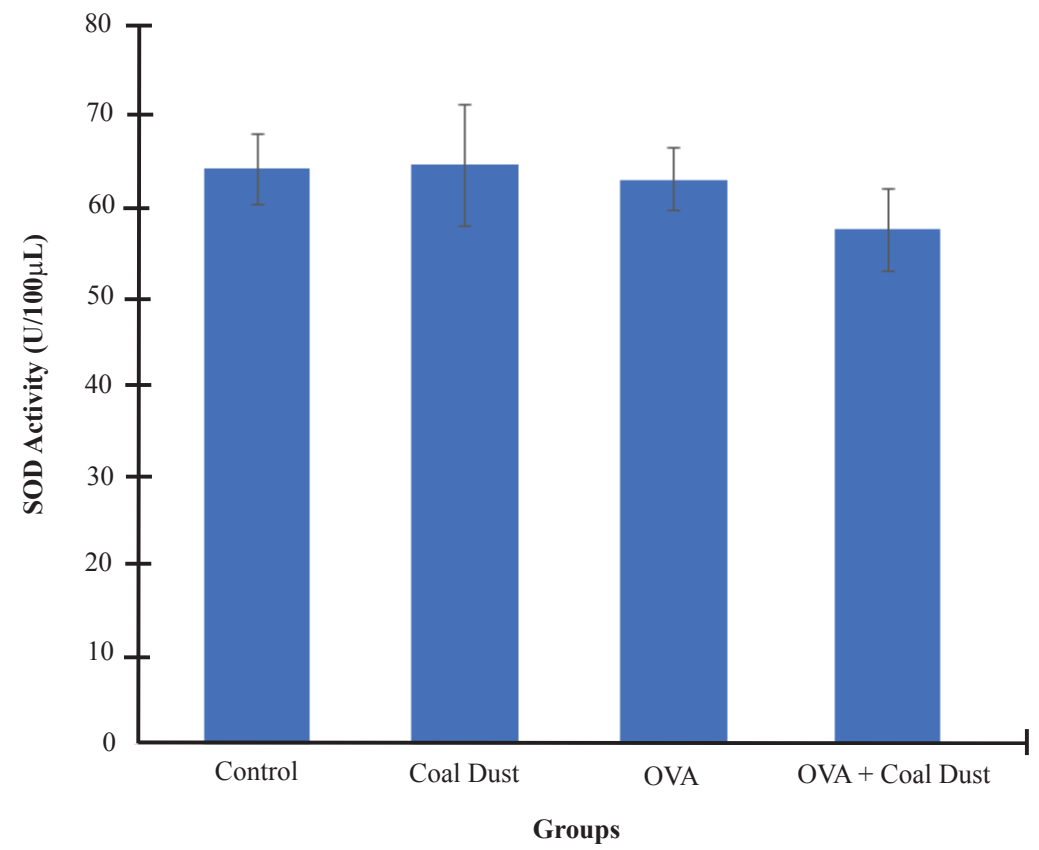

Figure 3. The Activity of serum SOD. Coal dust or OVA alone might no effect to the serum SOD activity. But the combination of OVA and coal dust could decrease the SOD activity in serum. 


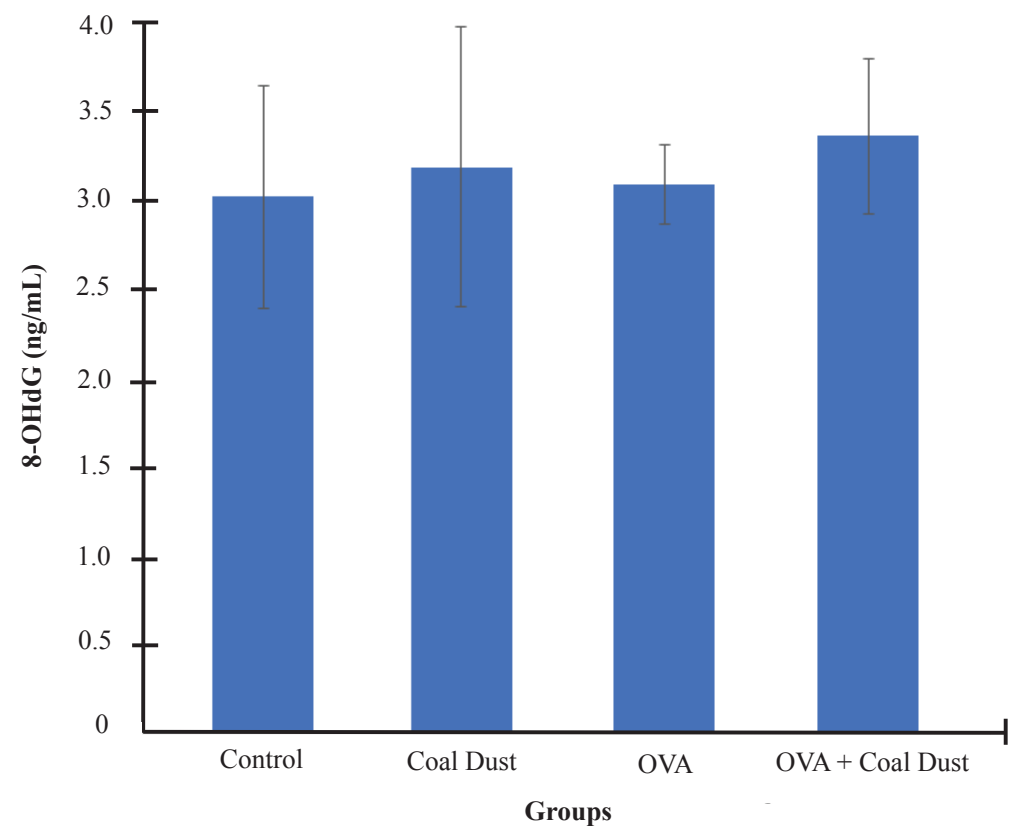

Figure 4. The concentration of serum 8-OHdG. There was a tendency of increasing serum 8-OHdG level. Combination of OVA and coal dust yielded the worst effect on DNA damage in serum. inflammation is characterized by the release of IL-13, a proinflammatory cytokine. $(7,21,22)$

The results of this study are in line with the results of the previous studies reporting that OVA-induced mice showed increasing inflammatory mediators in the lung tissue and bronchoalveolar fluid but showed no increment of the inflammatory mediators in the serum. The study also mentioned that the release of the inflammatory mediators and cells were influenced by several factors including the duration of exposure to the allergen and the severity of the disease (6,8,23-25). The exposure duration and the disease severity will determine the infiltration area of the cells and the inflammatory mediators. The acute and sub-chronic exposures only cause the release of the inflammatory cells and mediators in the perivascular area and will not result in endothelial damage that will consequently induce vascular leakage. $(24,26)$ Thes reports are supported by another study which identified that serum IL-13 will increase significantly in severe asthma condition.(27) Another study also showed that serum IL-13 concentration significantly increased when the inflammatory process occurred in chronic persistent conditions.(28)

This study also found that the serum SOD activity in the ovalbumin group was decreased compared to the group exposed to coal dust. Meanwhile, the decreasing SOD activity was higher in the combination group of OVA and coal dust exposure even though not statistically significant compared to other groups. This event may be related to the duration of the inflammatory process of 8 weeks OVA sensitization and 4 weeks of coal dust exposure which maybe has not been able to yield a substantial ROS production systemically. Several studies mentioned that ROS production determined the activity of endogenous antioxidants, one of which was SOD. The sources of ROS production are from the coal dust compounds. It can indirectly stimulate pro-inflammatory mediators secretion which will active inflammatory cells such as tumor necrosis factor (TNF)- $\alpha$ IL-13, and while also activates alveolar macrophages.(13,14,29,30) Several studies reported that the more ROS was produced.(31) One of the most important ROS produced was superoxide radicals. $(32,33)$

The superoxide radicals will send signals to the body to produce SOD to convert the radical into non-radical products. Therefore, the decrease of the SOD activity is one of the characteristics of the amount of ROS formed.(32,33) The trend of SOD serum activity showed similar trend the IL-13 serum concentration. Based on the mechanism previously explained, the inflammatory process has not occurred systemically and therefore the concentration of IL13 serum produced also influenced the SOD serum activity. This mechanism is supported by the result of another study which explained that the recurrent and prolonged inflammatory process in COPD leads to a significant decrement of serum SOD compared to the healthy group. (34) Besides that, the chronic coal dust exposure on coalfired power plant workers increased the serum MDA while significantly reduced the serum SOD.(35) 
In this study, it was also identified that the increment of the serum 8-OHdG concentration in the coal group was higher than the OVA group. On the other hand, the higher increment of the $8-\mathrm{OHdG}$ concentration was also shown in the combination group. However, the rise of 8-OHdG concentration was not statistically significant. These results were similar to the result of IL-13 and serum SOD activity. This may be regarding the duration of coal dust exposure, coal dust concentration exposed, and the inflammatory process that has not adequate enough to produce a certain amount of ROS that is able to trigger the oxidative stress leading to the systemic oxidative damage. The oxidative damage that is commonly observed are oxidative lipid damage indicated by an increment of MDA and oxidative DNA damage indicated by the rise of the 8-OHdG concentration. $(18,36)$ The results of this study are in line with the previous which reporting that 14-days coal dust exposure didn't increase the serum MDA yet significantly increased the MDA in the lung tissue and bronchoalveolar fluid of mice.(37)

\section{Conclusion}

Coal dust exposure for four weeks isn't adequate to induce oxidative DNA damage systemically in asthma mice model. For further research studies are necessary to examine subchronic coal dust exposure to determine the extent of the impact of coal dust to cause DNA oxidation.

\section{References}

1. Mims JM. Asthma: definition and pathophysiology. Int Forum Allergy Rhinol. 2015: 5: S2-6.

2. Global Initiative for Asthma (GINA). GINA Report 2017 update, Global Strategy for Asthma Management and Prevention. Fontana: GINA; 2017.

3. Zosky GR, Sly PD. Animal models of asthma. Clin Exp Allergy. 2007; 37: 973-88.

4. Bates JHT, Rincon M, Irvin CG. Animal model of asthma. Am J Physiol Lung Cell Mol Physiol. 2009: 297: L401-10.

5. Kumar RK, Herbert C, Foster PS. The "classical" ovalbumin challenge model of asthma in mice. Curr Drug Targets. 2008; 9: 485-94.

6. Ma Y, Ge A, Zhu W, Liu Y, Ji N, Zha W, et al. Morin attenuates ovalbumin-induced airway inflammation by modulating oxidative stress-responsive MAPK signaling. Oxid Med Cell Longev. 2016; 4: 1-13.

7. Sethi GS, Naura AS. Progressive increase in allergen concentration abrogates immune tolerance in ovalbumin-induced murine model of chronic asthma. Int Immunopharmacol. 2018; 60: 121-31.

8. Barlianto, W, Kusuma MSC, Karyono S, Mintaroem K. The development of allergic mouse model following chronic ovalbumin exposure. Jurnal Kedokteran Brawijaya. 2009; XXV: 1-5.

9. World Health Organization (WHO) [Internet]. Geneva: WHO; 2017. World Health Statistics 2017: Monitoring health for the SDGs [cited 2018 Aug 1]. Available from: https://www.who.int/gho/ publications/world_health_statistics/2017/en/.

10. Health Research and Development Agency. Basic Health Research/ Riset Kesehatan Dasar (RISKESDAS) 2017. Jakarta: Ministry of Health Republic of Indonesia; 2017.

11. Liu L, Poon R, Chen L, Frescura A, Montuschi P, Ciabttoni G, et al. Acute effect of air pollution on pulmonary function, airway inflammation, and oxidative stress in asthmatic children. Environ Health Perspect. 2009; 117: 668-74.

12. Kleniewska P, Pawliczak R. The participation of oxidative stress in pathogenesis of bronchial asthma. Biomed Pharmacother. 2017; 94: 100-8.

13. Rohr P, Kvitko K, da Silva FR, Menezes APS, Porto C, Sarmento M, et $a l$. Genetic and oxidative damage of peripheral blood lymphocytes in workers with occupational exposure to coal. Mutat Res: Genet Toxicol Environ Mutagen. 2013; 758: 23-8.

14. Zontek T, Ogle BR, Hollenbeck S, Jankovic JT. A comparison of occupational exposure limits and their relationship to reactive oxide species. J Chem Health Safety. 2017; 24: 29-35.

15. Pinho RA, Bonatto F, Andreas M, Jr MLCF, Ritter C, Klamt F, et al. Lung oxidative response after acute coal dust exposure. Environment Res. 2004; 96: 290-7.

16. Kania N, Setiawan B, Nurdiana, Widodo MA, Kusuma HMSC. Peroxidative index as a novel marker of hydrogen peroxide involvement in lipid peroxidation from coal dust exposure. Oxid Antioxid Med Sci. 2012; 1: 209-15.

17. Armutcu F, Gun BD, Altin R, Gurel A. Examination of lung toxicity, oxidant/antioxidant status and effect of erdosteine in rats kept in coal mine ambience. Environt Toxicol Phramacol. 2007; 24: 10613.

18. Cho YS, Moon H. The role of oxidative stress in pathogenesis of asthma. Allergy Asthma Immunol Res. 2010; 2: 183-7.

19. Tzortzaki EG, Minakou K, Neofytou E, Tsikritsaki K, Samara K, Avgousti $\mathrm{M}$, et al. Oxidative DNA damage and somatic mutations: a link to the molecular pathogenesis of chronic inflammatory airway diseases. CHEST. 2012; 141: 1243-50.

20. Arent CO, Reus GZ, Abelaira HM, Ribeiro KF, Steckert AV, Mina F, et $a l$. Synergist effect of n-acetylcysteine and deferoxamine treatment on behavioral and oxidative parameters induced by chronic mild stress in rats. Neurochemistry International. 2012; 61: 1072-80.

21. Rael EF, Lockey RF. Interleukin-13 signaling and its role in asthma. WAO Journal. 2011; 4: 54-64.

22. Gour N, Wills-Krap M. IL-4 and IL-13 signaling in allergic airway disease. Cytokine. 2015; 75: 68-78.

23. Fallahi M, Keyhanmanesh R, Khamaneh AM, Saadatlou MAE, Saadat S, Ebrghimi H. Effect of Alpha-Hederin, the active constituent of Nigella sativa, on miRNA-126, IL-13 mRNA levels and inflammation of lungs in ovalbumin-sensitized male rats. Avicenna J Phytomed. 2016; 6: 77-85.

24. Kianmehr M, Ghorani V, Boskabady MH. Animal model of asthma, various method and measured parameters: a methodological review. Iran J Allergy Asthma Immunol. 2016; 15: 445-65.

25. Hasegawa T, Uga H, Mori, Kurata H. Increased serum IL-17A and Th2 cytokine levels in patients with severe uncontrolled asthma. Eur Cytokine Betw. 2017; 28: 8-18.

26. Locke NR, Royce SG, Wainewright JS, Samuel CS, Tang ML. Comparison of airway remodeling in acute, subacute, and chronic models of allergic airways disease. Am J Respir Cell Mol Biol. 2007; 36: 625-32. 
27. Cai F, Hornauer H, Peng K, Schofield CA, Scheerens H, Morimoto AM. Bioanalytical challenges and improved detection of circulating levels of IL-13. Bioanalysis. 2016; 8: 323-32.

28. Joseph J, Benedict S, Al-sowaidi S, Joseph M, Zoubeidi T. Serum interleukin-13 levels are elevated in mild and moderate persistent asthma. Internet J Asthma Allergy Immunol. 2004; 4: 1-7. doi: $10.5580 / 240 \mathrm{f}$.

29. Bishopp A, Sathyamurthy R, Manney S, Webbster C, Krishna MT, Mansur AH. Biomarker of oxidative stress and antioxidants in severe asthma a prospective case-control study. Ann Allergy Asthma Immunol. 2017; 118: 445-51.

30. Sahiner UM, Birben E, Erzurum S, Sackesen C, Kalayci O. Oxidative stress in asthma. WAO Journal. 2011; 4: 151-8.

31. Dickinson JD, Alevy Y, Malvin NP, Patel KK, Gusten SP, Holtzman MJ, et al. IL13 activates autophagy to regulate secretion in airway epithelial cells. Autophagy. 2016; 12: 397-409.

32. Lu X, Wang C, Liu B. The role of Cu/Zn-SOD and Mn-SOD in the immune response to oxidative stress and pathogen challenge in the clam Meretrix meretrix. Fish Shellfish Immunol. 2015; 42: 58-65.
33. Ighodaro OM, Akinloye OA. First line defence antioxidantssuperoxide dismutase (SOD), catalase (CAT) and glutathione peroxidase (GPX): Their fundamental role in the entire antioxidant defence grid. Alex J Med. 2017; 2017: 1-7. doi: 10.1016/j. ajme.2017.09.001. 1.

34. Bajpai J, Prakash V, Kant S, Verma AK, Srivastava A, Bajaj DK, et al. Study of oxidative stress biomarkers in chronic obstructive pulmonary disease and their correlation with disease severity in north Indian population cohort. Lung India. 2017; 34: 324-29.

35. Kaur S, Gill MS, Gupta K, Manchanda KC. Effect of occupation on lipid peroxidation and antioxidant status in coal-fired thermal plant workers. Int J Appl Basic Med Res. 2013; 3: 93-7.

36. Fenga C, Gangemi S, Teodoro M, Rapisarda V, Golokhvast K, Anisimov NY, et al. 2017. 8-hydroxydeoxyguanosine as a biomarker of oxidative DNA damage in workers exposed to low-dose benzene. J Toxicol Rep. 2017; 4: 291-5.

37. Kania N, Setiawan B, Nurdiana, Widodo MA, Kusuma HMSC. Oxidative stress in rats caused by coal dust plus cigarette smoke. Univ Med. 2011; 30: 80-7. 